\title{
A new species of Begonia sect. Diploclinium, Begonia bhutanensis, from Bhutan
}

\author{
P. Gyeltshen ${ }^{1}$, M. Hughes ${ }^{2} \&$ S. Jamtsho 3 \\ ${ }^{1}$ Bumthang Forest Division, Department of Forest and Park Services, \\ MoAF, Trongsa, Bhutan \\ gyeltshenforest@gmail.com \\ ${ }^{2}$ Royal Botanic Garden Edinburgh, 20a Inverleith Row, \\ Edinburgh, EH3 5LR, Scotland, U.K. \\ ${ }^{3}$ Zhemgang Forest Division, Department of Forest and Park Services, \\ MoAF, Zhemgang, Bhutan
}

\begin{abstract}
Begonia bhutanensis P.Gyeltshen \& M.Hughes (Begoniaceae) is described from the warm broadleaved forests of Zhemgang district in Bhutan. It is assigned to Begonia sect. Diploclinium as it has a tuberous habit and bifid placentae and is similar to Begonia rubella Buch.-Ham. ex D.Don, but differs in having fimbriate bracts (not entire) and rounded wings on the capsule (not elongate triangular). A key to species of Begonia sect. Diploclinium in Bhutan is provided.
\end{abstract}

Keywords. Begoniaceae, conservation, taxonomy, Zhemgang

\section{Introduction}

Bhutan sits at the nexus between the diverse floras of the Himalayas and northeast India, and for its area has a rich complement of 17 Begonia L. species (Hughes et al., 2015 onwards). Other than the recent new record of Begonia flaviflora H.Hara by Gyeltshen et al. (2021) no work on the genus in Bhutan has been published since the account in the Flora of Bhutan thirty years ago (Grierson, 1991), whereas in the surrounding areas of Nepal and northeast India several new species have been described (Rajbhandary et al., 2010; Taram et al., 2020, 2021; Krishna et al., 2021). Recent fieldwork by one of the authors brought to light a Begonia species which did not match any of the known species from the region, and correspondence ensued between the authors in Bhutan and Edinburgh in order to identify it. The wild collected plant was found to match a plant in cultivation at the Royal Botanic Garden Edinburgh, brought to the garden as a seed donation in 1985 which was originally collected in the Zhemgang District ["Shamgong"] of Bhutan and initially identified as Begonia rubella Buch.-Ham. ex D.Don. However, after examination of ten specimens of Begonia rubella in the Edinburgh herbarium from across its range in Nepal, it became clear the species from Bhutan differed from B. rubella in several characters. The species in question is described here as new and endemic to Bhutan, and is placed in Begonia sect. Diploclinium (Lind1.) A.DC. due to its tuberous habit and bifid placentae. 


\section{Key to Begonia sect. Diploclinium in Bhutan}

1a. Leaves peltate

B. josephi

1b. Leaves basifixed

2a. Leaves pilose above, minutely bullate, often variegated red/green B. picta

$2 \mathrm{~b}$. Leaves glabrous or with sparse short hairs above, smooth, uniform green 3

3a. Plant caulescent B. pedunculosa

3b. Plant acaulescent, sometimes with a few cauline leaves on the peduncle 4

4a. Plant stoloniferous, fruit with equal wings B. dioica

4b. Plant not stoloniferous, fruit with unequal wings 5

5a. Petioles puberulent, plant $<20 \mathrm{~cm}$ tall B. ovatifolia

5b. Petioles glabrous, plant $>25 \mathrm{~cm}$ tall 6

6a. Androecium asymmetric, bracts entire, largest capsule wing triangular B. rubella

6b. Androecium symmetric, bracts fimbriate-laciniate, largest capsule wing rounded B. bhutanensis

Begonia bhutanensis P.Gyeltshen \& M.Hughes, sp. nov. (§ Diploclinium) Resembles Begonia rubella in habit, but differs in having fimbriate-laciniate bracts (not entire), rounded wings on the capsule (not elongate triangular), and a symmetric androecium with sub-uniformly sized anthers (not asymmetric with markedly heteromorphic anthers (Rajbhandary et al., 2011)). - TYPE: Bhutan, Zhemgang District, Zhangling, Shingkhar block, $1070 \mathrm{~m}, 27^{\circ} 08^{\prime} 24.37^{\prime \prime} \mathrm{N} 90^{\circ} 55^{\prime} 16.34^{\prime \prime} \mathrm{E}, 26$ August 2019, P. Gyeltshen \& S. Jamtsho 42 (holotype THIM; isotype THIM). (Fig. $1,2)$

Plant monoecious, tuberous, herbaceous, $35-50 \mathrm{~cm}$ tall. Tuber subglobose, c. $1.9 \times$ $1.6 \mathrm{~cm}$, a creeping tuberous rhizome is also present, c. $4 \times 0.8 \mathrm{~cm}$, forming on an adventitious root from near the apex of the tuber. Stem erect or slightly pendent at distal portion, present during flowering, $44-45 \mathrm{~cm}$ long, red, glabrous, lowermost internodes 4-6 mm apart, unbranching, 2-4 leaves per stem. Stipules ovate, 1.5-2 $\times$ $0.8-1.2 \mathrm{~cm}$, papery, keeled, apex cuspidate, margin entire, adaxial surface glabrous. Leaves alternate; petioles cylindrical, 3-12 $\mathrm{cm}$ long, 2-3 mm thick, reddish green, glabrous; lamina broadly ovate, $6-17 \times 5-16 \mathrm{~cm}$, basifixed, base cordate, margin subentire and sparsely white ciliate, apex broadly acuminate, venation palmatereticulate, veins 5-6; adaxial surface with sparsely scattered appressed white hairs c. 2 $\mathrm{mm}$ long; abaxial surface paler green, glabrous. Inflorescences terminal or axillary on stems with 4-5 internodes, bisexual, protandrous, dichasial cymes with 4-5 branches, 



Fig. 1. Begonia bhutanensis P.Gyeltshen \& M.Hughes. A, B. Female flowers front and side view showing ovary. C. Male flowers front and side view. D. Ovary after dehiscence of tepals. E. Cross section of ovary showing two placentae per locule. F. Habit. G. Inflorescence detail showing fimbriate bracts. H. Globose tuber and tuberous rhizome. A-H of a cultivated plant at the Royal Botanic Garden Edinburgh [Accession 19860709]; H of the type collection. (Photos: A-G, M. Hughes; H, S. Jamtsho) 


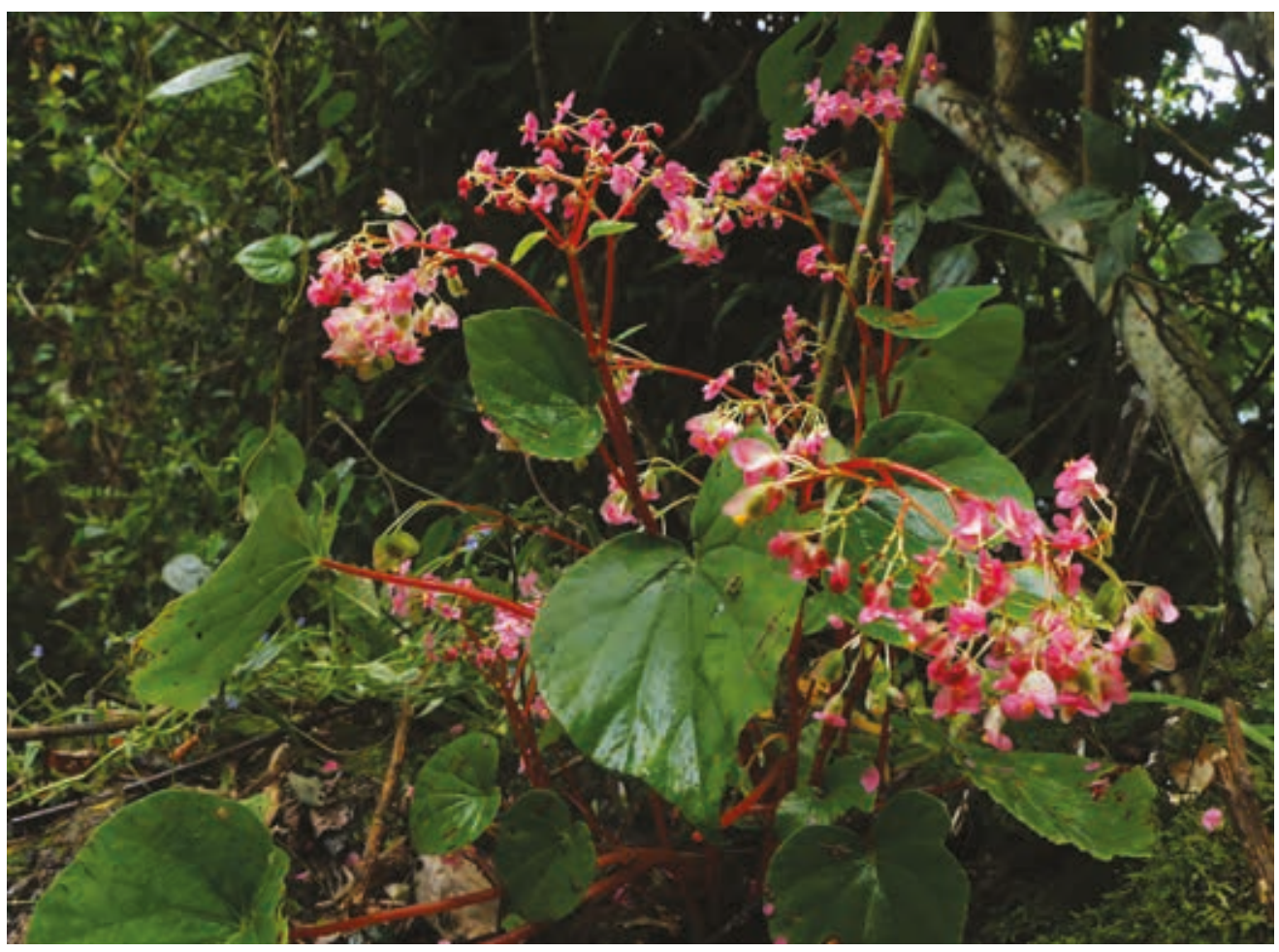

Fig. 2. Habitat and habit of Begonia bhutanensis P.Gyeltshen \& M.Hughes at the type locality. (Photo: S. Jamtsho)

erect to pendent; peduncles cylindrical, up to $26 \mathrm{~cm}$ long, reddish green or green, glabrous, bracts oblong, c. $5 \times 2 \mathrm{~mm}$, margin long fimbriate, apex obtuse, base truncate, glabrous. Staminate flower: pedicel c. 1-1.7 cm long, pale green, glabrous; tepals 4 , pale pink to pink, margin entire; outer 2 orbicular, 7-9 $\times 6-8 \mathrm{~mm}$, glabrous, apex and base rounded, margin entire, up to 8-veined; inner 2 narrowly obovate, $6-8 \times 3-4 \mathrm{~mm}$, glabrous, apex rounded, base obtuse; androecium loosely globose, stamens c. 20-25, 1-2 mm long, on a c. $2.5 \mathrm{~mm}$ column, anthers obovate-oblong, golden yellow, basal anthers sessile, central anthers on a c. $0.5 \mathrm{~mm}$ filament, apex rounded and slightly extended. Pistillate flower: pedicel up to $3 \mathrm{~cm}$ long, pale green to light pinkish-green, glabrous, tepals 3-4, pale pink to pink, glabrous, margin entire; outer 2 orbicular, 6-8 $\times 7-10 \mathrm{~mm}$, orbicular, apex rounded, base truncate; inner 1-2 elliptic, 6-7 × 3-5 mm, base sub-obtuse; ovary green sometimes light pinkish on the wings, glabrous, with 3 subequal wings, 3 locules, placentation axillary, 2 branches per locule; styles 3 , golden yellow, Y-shaped, c. $3 \mathrm{~mm}$ long, fused at base; stigma spiralled, spiral part papillose. Fruits green to pale pinkish green, trigonous-globose, c. $1.7 \times 0.6 \mathrm{~cm}$, glabrous; dorsal wing c. $1.7 \times 1 \mathrm{~cm}$, slightly falcate at apex, narrower towards the base, lateral wings c. $1.5 \times 0.2-0.3 \mathrm{~cm}$. 
Distribution and habitat. Endemic to Bhutan, Zhemgang District. Grows on moist soil in shady areas of warm broadleaved forest at $1070 \mathrm{~m}$ elevation. Associated species include Impatiens tripetala Roxb. \& DC.; Galium elegans Wall.; Gonostegia triandra Miq.; Cyanotis vaga (Lour.) Schult. \& Schult.f.; Chromolaena odorata (L.) R.M.King \& H.Rob. and Asplenium delavayi (Franch.) Copel.

Phenology. Flowering and fruiting from August to September.

Etymology. The specific epithet of the new species refers to Bhutan, where the type was collected.

Provisional IUCN conservation assessment. Begonia bhutanensis is known from the type location and one other location without precise locality (the source of the cultivated plant). The type locality has 3 mature individuals growing in the moist soil on the banks at the side of a road. The habitat has recently been severely disturbed due to road maintenance. Widening of the roads in the future may lead to complete loss of its natural habitat. It is expected that this species may occur in intermediate areas, but so far, no more populations have been observed. Although further survey is required on its distribution and population size, this species should be considered to be Critically Endangered (CR B2ab(iii); D) based on the above knowledge and in reference to the IUCN Red List Categories and Criteria (IUCN Standards and Petitions Committee, 2019).

Additional specimen examined. Originally from BHUTAN: Zhemgang District ["Shamgong"]: Broad s.n., cultivated at the Royal Botanic Garden Edinburgh [19860709], 16 Sep 2019, M. Hughes s.n. (E, THIM).

ACKNOWLEDGEMENTS. The authors would like to express sincere gratitude to the Director of Department of Forest and Park Services, Chief Forestry Officers and staff of Zhemgang and Bumthang Forest Divisions for their constant motivation and encouragement. We thank David Tricker and Neil Watherston for maintaining the living collection in the RBGE.

\section{References}

Grierson, A.J.C. (1991). Begoniaceae. In: Grierson, A.J.C. \& Long, D.G. (eds) Flora of Bhutan, vol. 2, pt. 1, pp. 237-246. Edinburgh: Royal Botanic Garden Edinburgh.

Gyeltshen, P., Jamtsho, S., Wangchuk, S. \& Subba, D.B. (2021) Begonia flaviflora Hara (Begoniaceae): a new record to the flora of Bhutan. J. Threat. Taxa 13: 18050-18053.

Hughes, M., Moonlight, P.W., Jara, A. \& Pullan, M. (2015 onwards). Begonia Resource Centre. http://padme.rbge.org.uk/begonia/. Accessed 28 Oct. 2019.

IUCN Standards and Petitions Committee (2019). Guidelines for Using the IUCN Red List Categories and Criteria. Version 14. Prepared by the Standards and Petitions Committee. Available from: http://iucnredlist.org/documents/RedListGuidelines.pdf. 
Krishna, N., Pradeep, A.K., Amrutha, A. \& Jayakrishnan, T. (2021). A new species and a new record of Begonia (sect. Platycentrum, Begoniaceae) from northeastern India. Phytotaxa 482(3): 261-267.

Rajbhandary, S., Hughes, M. \& Shrestha, K.K. (2010). Three new species of Begonia Sect. Platycentrum from Nepal. Gard. Bull. Singapore 62: 151-162.

Rajbhandary, S., Hughes, M. \& Shrestha, K.K. (2011). Male flower and androecium morphology of Begonia species in Nepal. J. Taxon. Biodivers. Res. 5: 19-25.

Taram, M., Borah, D., Krishna, N., Pradeep, A.K., Amrutha, A. \& Hughes, M. (2020). Begonia oyuniae (Begonia sect. Monophyllon, Begoniaceae), a remarkable new species from Northeast India. Gard. Bull. Singapore 72: 109-115.

Taram, M., Borah, D. \& Hughes, M. (2021). Begonia kekarmonyingensis (Begoniaceae), a new species from Arunachal Pradesh, Northeast India. Phytotaxa 494(3): 268-272. 